\title{
The Effectiveness of Teacher Performance in Terms of the Aspects of Principal Leadership, Organizational Culture, and Teacher Competence
}

\author{
Kevin Indajang ${ }^{1}$, Sherly ${ }^{2}$, Fitria Halim ${ }^{3}$, Acai Sudirman ${ }^{4 *}$ \\ 1,2,3,4 Sultan Agung College of Economics, Indonesia \\ *Corresponding Email:acaivenly@stiessultanagung.ac.id
}

\begin{abstract}
This study will analyze principal leadership, organizational culture, and teacher competence on teacher performance. This study used a quantitative approach to causality. The data were collected through documentation and questionnaires. This study used a sample of 98 respondents to determine the sample size using the saturated sample formula. A partial least square was applied to examine the relationship of teacher performance, principal leadership, organizational culture, and teacher competence. The results of this study showed that of the three hypotheses formulated, two hypotheses were rejected, including the effect of the principal leadership variable on the teacher performance variable, in which the results did not have a significant effect, and the effect of the teacher competence variable on the teacher performance variable that obtained the same results, in which it did not have a significant effect. Meanwhile, the organizational culture variable had a significant effect on teacher performance. Through the findings of this study, it is expected to provide additional information for various parties, especially the Sultan Agung Education Foundation and the Education Authority of Pematangsiantar City in determining policies related to improving teacher performance.
\end{abstract}

Keywords: Principal Leadership, Organizational Culture, Teacher Competence, Teacher Performance

\section{INTRODUCTION}

The urgency of school attendance as a forum for conducting education and performing its functions properly is to produce quality human resources to face the dynamics of environmental change and the times [1], [2], and [3]. The success parameters applied in the teaching and learning process of a teacher include matters relating to the number of achievements obtained by the teacher and optimizing their performance [4] [5].

To produce the best human resources, a teacher needs his role in carrying out his duties effectively. In general, many constituents affect the level of performance, one of which is the principal's leadership [6]. Over the last few decades, many studies have stated and attempted to validate the relationship between principal leadership, teacher performance and the learning process of student [7] \& [8]. The role of a leader is very important because the main element for the effectiveness of a school is the principal's leadership style [9]. As explained by [10] the success or progress of a school is strongly influenced by the pattern of leadership. This is reinforced by the opinion [11], which states that school principals must have a good spirit of professionalism to maximize the implementation of school management. Furthermore, the right leadership style of the principal will motivate teachers to improve their work morale [12]. The above opinion is supported by the findings [13] and [14], stating a significant influence between the principal's leadership and teacher performance.

A complex effort is needed to achieve optimal teacher performance through the development of various interrelated factors [15]; [16]; [17]; [18]. One of the representative competitive advantages of an organization can be seen from implementing a good organizational culture [19]. The optimal representation of the quality of education will be seen when there is an increase in the work culture and organizational culture in schools [20]. Research [21] and [22], stated that an increase in one's performance could occur because one 
of them is significantly influenced by organizational culture.

In achieving performance optimization, a teacher must be able to develop all of his abilities related to competence and create a learning atmosphere that is more comfortable and conducive for his students [23]. Quality improvement in education will only be realized if teachers are motivated, creative, innovative, dynamic, and active in every job they do [24]; [25], and [26]. Based on government regulations as outlined in Article 10 of Law no. 14 of 2005 concerning teachers and lecturers [27], it is explained that a teacher in carrying out an educational learning process is required to have competence integrated and skilled. The professionalism of a teacher in teaching will be seen from the mastery of the sub competencies of the structure and scientific methods of a particular field, so the implications of this mastery are believed to be able to improve performance [28]. The above statement is supported by the findings [29] and [30], whose research results conclude that improving a teacher's performance can be significantly boosted by the competence he has.

Factors supporting performance improvement as stated above are not all acceptable. Several studies have stated that principal's leadership, organizational culture, and competence have no significant effect on teacher performance. Research result[9] said an increase in a teacher's performance was not driven significantly by the leadership applied by the principal. Research submitted by [31]; [32] stated that a teacher's competence did not significantly influence teacher performance. This can happen because there are fewer teachers who play an active role in helping actualize prospective students.

\section{METHOD}

The quantitative causality approach used in this study is oriented to the theoretical model assessed by PLS-SEM analysis in a two-stage process. First, the research data analyzed for validity and reliability using Cronbach's alpha testing, composite reliability, outer loading, and average variance extracted. Then, perform a Confirmatory Factor Analysis analysis to check the model's fit and the reliability of the model and discuss the hypothesis through the variance-based Structural Equation Model (SEM) [33]. The instrument used for this study used a questionnaire using a Likert scale, namely (1) which stated "very dissatisfied to" (5) "very satisfied". The measurement of the dependent and independent variables uses previous references relevant to the research topic and research variables. The measurement of the dependent variable, namely the teacher's performance is measured using Law of the Republic of Indonesia number 14 of 2005 about Teachers and Lecturers [27], which consists of 3 indicators. Furthermore, for the first independent variable, namely the principal's leadership, it is measured usingPermendiknan number 13 of 2007 concerning Standards for Principals/Madrasah [34], consisting of 5 indicators. The second independent variable, namely organizational culture is measured using previous research [35] which consists of 4 indicators. Then for the third independent variable, namely teacher competence, it is measured using the law of the Republic of Indonesia number 14 of 2005 article 8 [27] which consists of 4 indicators. Therefore, the conceptual framework of this research can be described in Figure 1 below:

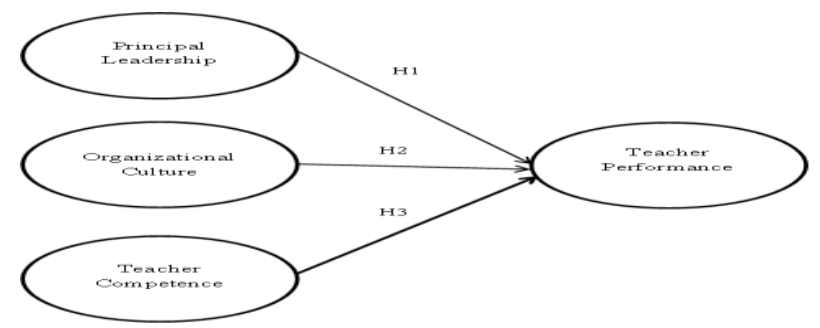

Picture 1. Research Framework Model

\section{RESULT}

The number of respondents who have filled out the questionnaire is 98 teachers. The general characteristics of respondents in this study will clearly be described in table 1 below:

Table 1. General Profile of Respondents

\begin{tabular}{|c|c|c|c|}
\hline \multirow{2}{*}{ Category } & Details & amount & Percentage \\
\hline \multirow{2}{*}{ Gender } & Men & 23 & $23.47 \%$ \\
& Woman & 75 & $76.53 \%$ \\
\hline \multirow{4}{*}{ Age } & 2 20 years & 1 & $1.02 \%$ \\
& 21-30 years old & 13 & $13.27 \%$ \\
& $31-40$ years old & 34 & $34.69 \%$ \\
& $41-50$ years old & 23 & $23.47 \%$ \\
Level of & $>50$ years & 27 & $27.55 \%$ \\
education & high school & 2 & $2.04 \%$ \\
& Bachelor degree & 81 & $82.65 \%$ \\
& Level 2 & 15 & $15.31 \%$ \\
\hline \multirow{3}{*}{ Work unit } & kindergarten & 15 & $15.31 \%$ \\
& SD & 33 & $33.67 \%$ \\
& middle school & 22 & $23.47 \%$ \\
& high school & 28 & $27.55 \%$ \\
\hline
\end{tabular}




\begin{tabular}{|c|c|c|c|}
\hline & $<5$ Years & 15 & $15.31 \%$ \\
& 6-10 Years & 21 & $21.43 \%$ \\
Years of & 11-20 Years & 30 & $30.61 \%$ \\
service & 21-30 Years & 17 & $17.35 \%$ \\
& $>20$ Years & 15 & $15.31 \%$ \\
\hline
\end{tabular}

Source: data processing results (2020)

\subsection{Outler Model Measurement}

The data obtained from the research questionnaire were processed using the SmartPLS version 3.2.9 application with management guidelines from[36]. In the measurement of the outer model, the tests carried out are validity tests and reliability tests. The loading factor and AVE determine convergent validity testing with the condition that the loading factor is above 0.7 and the AVE value is 0.5 [33]. Testing the reliability of the model according to [33] seen from the value of cronbanch's alpha and composite reliability (CR) which has a value greater than 0.7. In the following, an explanation of the measurement of the model's outlet is presented using table 2 below:

Table 2. Outler Model Measurement Results

\begin{tabular}{|l|c|c|c|c|}
\hline Construct/item & $\begin{array}{c}\text { Outler } \\
\text { Loadings }\end{array}$ & $\begin{array}{c}\text { Cronbach' } \\
\text { alpha }\end{array}$ & CR & AVE \\
\hline $\begin{array}{l}\text { Principal } \\
\text { Leadership }\end{array}$ & & $\mathbf{0 . 9 2 8}$ & $\mathbf{0 . 9 4 6}$ & $\mathbf{0 . 7 7 7}$ \\
\hline KS1 & 0.926 & & & \\
\hline KS2 & 0.842 & & & \\
\hline KS3 & 0.868 & & & \\
\hline KS4 & 0.860 & & & \\
\hline KS5 & 0.909 & & & \\
\hline $\begin{array}{l}\text { Organizational } \\
\text { culture }\end{array}$ & & $\mathbf{0 . 9 4 3}$ & $\mathbf{0 . 9 5 9}$ & $\mathbf{0 . 8 5 4}$ \\
\hline BO1 & 0.919 & & & \\
\hline BO2 & 0.922 & & & \\
\hline BO3 & 0.965 & & & \\
\hline BO4 & 0.889 & & & \\
\hline $\begin{array}{l}\text { Teacher } \\
\text { Competence }\end{array}$ & & $\mathbf{0 . 9 5 5}$ & $\mathbf{0 . 9 6 8}$ & $\mathbf{0 . 8 8 2}$ \\
\hline KT1 & 0.964 & & & \\
\hline KT2 & 0.929 & & & \\
\hline KT3 & 0.904 & & & \\
\hline KT4 & 0.958 & & & \\
\hline $\begin{array}{l}\text { Teacher } \\
\text { Performance }\end{array}$ & & $\mathbf{0 . 9 2 8}$ & $\mathbf{0 . 9 5 4}$ & $\mathbf{0 . 8 7 3}$ \\
\hline KG1 & 0.934 & & & \\
\hline KG2 & 0.949 & & & \\
\hline KG3 & 0.920 & & & \\
\hline Source: & & & & \\
\hline
\end{tabular}

Source: data processing results (2020)

In testing the validity test presented in table 2 above, it is known that the value of each loading factor on the indicators of the principal's leadership variable, organizational culture, teacher competence and teacher performance is above 0.7 and above 0.5 for the average variance value extracted (AVE). Furthermore, the value for each of the above reliability values obtained for each research variable is above 0.7 which can be explained: principal leadership gets 0.946 , organizational culture gets 0.959 , teacher competence gets 0.968 and teacher performance gets 0.954 . Furthermore, Cronbach's alpha values obtained for each variable above 0.7 indicate that all research variables have good reliability values.

\subsection{Inner Model Measurement}

The value of $\mathrm{R}$-square is a value that shows the ability of exogenous variables to build endogenous variables. According to [37] there are three categories of $\mathrm{R}$-square values, if the $\mathrm{R}$-square value is 0.19 the relationship between exogenous variables forming endogenous variables is weak, if it is 0.33 it means the relationship is moderate and if the value is 0.67 it means that the relationship is strong. While [38] states that if the $\mathrm{R}$-square value is more than 0.67 , the relationship between endogenous and exogenous is very strong. The explanation of the results of the calculation of the Rsquare value can be seen in table 3 below:

Table 3. Calculation results of the R-Square nilai value

\begin{tabular}{|c|c|c|}
\hline Information & $R$ Square & $R$ Square Adjusted \\
\hline Teacher Performance & 0.509 & 0.494 \\
\hline
\end{tabular}

Source: data processing results (2020)

The significant criterion is seen from the p-value. With a significance level of $5 \%$, if the p-value between exogenous and endogenous variables is less than 0.05 , it means that the exogenous variable has a significant effect on the endogenous variable, on the other hand, if the value is greater than 0.05 , it means that the exogenous variable has no significant effect on building endogenous variables. The following presents the results of the hypothesis test which are explained in Figure 2 and Table 4 below:

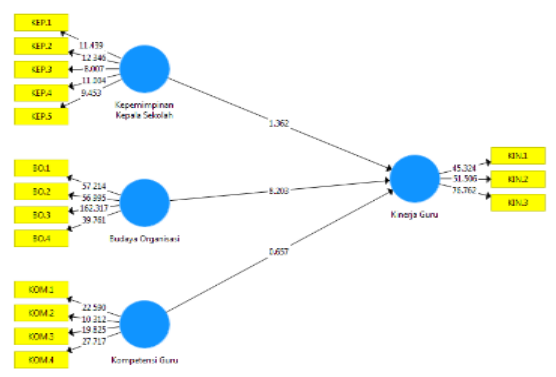

Figure 2. Inner Model Display 
Table 4. Path Coefficients . Test Results

\begin{tabular}{|c|c|c|c|c|}
\hline $\begin{array}{c}\text { Path Between } \\
\text { Variables }\end{array}$ & $\begin{array}{c}\text { Coefficie } \\
\boldsymbol{n t}\end{array}$ & tcount & $\boldsymbol{P}$-Value & Conclusion \\
\hline $\begin{array}{c}\text { Principal } \\
\text { Leadership >> } \\
\text { Teacher } \\
\text { Performance }\end{array}$ & 0.108 & 1.362 & $\mathbf{0 . 1 7 4}$ & Rejected \\
\hline $\begin{array}{c}\text { Organizational } \\
\text { Culture >> } \\
\text { Teacher } \\
\text { Performance }\end{array}$ & 0.669 & 8,203 & $\mathbf{0 . 0 0 0}$ & $\begin{array}{c}\text { Be } \\
\text { accepted }\end{array}$ \\
\hline $\begin{array}{c}\text { Teacher } \\
\text { Competence } \\
\text { >> Teacher } \\
\text { Performance }\end{array}$ & 0.052 & 0.080 & $\mathbf{0 . 5 1 2}$ & Rejected \\
\hline
\end{tabular}

Source: data processing results (2020)

Meanwhile, the organizational culture variable has a significant effect on teacher performance.

\section{DISCUSSION}

\subsection{The Effect of Principal's Leadership on Teacher Performance}

This can be influenced by the leadership of the principal who has not been optimal in carrying out his responsibilities at school, as a result, weakening the ability of teachers in upgrading [39]. The findings of this research are in line with the research results [40] and [41], whose research results report the leadership of the principal does not directly influence an escalation or decline in teacher performance, but there are more vital things that can encourage an increase in teacher performance, such as encouragement or the activity environment. On the other hand, the results obtained in this studycontradiction with the results of the submitted study [42]; [13]; [43], who reported that there was a significant effect of principal's leadership on teacher ability.

\subsection{The Influence of Organizational Culture on Teacher Performance}

Representatives of strengthening organizational culture in schools can suppress the increase in a teacher's performance [9]. On the other hand, maintaining a transparent organizational culture can support teachers in carrying out their profession following the values and norms of society[44]. The findings of this research are in agreement with the research results[45]; [46]; [47], whose findings report that there is a significant effect of organizational culture on teacher performance. The practice of a pleasant organizational culture encourages teachers to carry out their duties competently and the impact will be seen from the results of the activities they have undertaken [48]. The results of this study contradict the results of research submitted by [49], who reported that there was no significant effect of organizational culture on teacher performance. Research findings [50], also detects similar results regarding the increase in teacher performance not influenced by organizational culture.

\subsection{The Influence of Teacher Competence on Teacher Performance}

The description of the third hypothesis test above, informed that there is no significant effect between teacher competence on teacher performance. When someone has good social competence and reliable competence with the help of optimistic thinking, in fact it is not enough to encourage him to improve his professional results [51]. The findings of this research are in line with the research results [52], whose findings report that there is no significant effect between teacher competence on teacher performance. Although a teacher has sufficient competence, but the incentives provided are not following the level of competence he has, then the teacher does not have great enthusiasm for activities as a result can limit his performance [32]. However, some studies carry out similar research and get results that contradict the results of this research. Research attempted by [53]; [54]; [55], reported that teacher competence had a significant impact on teacher performance. A teacher who has good competencies, including academic competence, character competence, social competence, and professional competence, is believed to help the person improve his performance. The manifestation of the continuous increase in teachers' ability will be seen from the competencies they have [56].

\section{CONCLUSION}

The results of the test of the influence between the principal's leadership and teacher performance obtained positive but not significant results. The test of the influence of school organizational culture with teacher performance obtained positive and significant results. The results of the test of the influence between the 
principal's leadership and teacher performance obtained positive but not significant results.

\section{AUTHORS' CONTRIBUTIONS}

Kevin indajang as the first writers who carried out the research activity, Sherly and Fitria Halim as the second and third authors who had compiled the article from the beginning to the end, Acai Sudirman as the corresponding writer had edited the manuscript and carried out the review process.

\section{ACKNOWLEDGMENTS}

The author would like to thank the Sultan Agung College Foundation which has permitted this research and all school principals and teachers from kindergarten to high school units who have contributed to this research.

\section{REFERENCES}

[1] M. Jasour and S. Maleki Avarsin, "The Relationship Between Attributional Style and Spiritual Intelligence and Job Performance of Employees of Tabriz University of Medical Sciences," res. Dev. Med. Educ., vol. 5, no. 2, pp. 55-61, 2016, doi:10.15171/rdme.2016.012.

[2] PA Hamid, A. Suriansyah, and Ngadimun, "The Relationship between Interpersonal and Emotional Intelligence on Teacher Performance," J. K6, Educ. Manag., vol. 2, no. 1, pp. 71-77, 2019, doi:10.11594/jk6em.02.01.10.

[3] AN Sari, Sulaiman, and A. Suriansyah, "The Contribution of Emotional Intelligence and Interpersonal Communication on Teacher Performance Through Job Satisfaction," J. K6, Educ. Manag., vol. 2, no. 3, pp. 229-233, 2019, doi: 10.11594/jk6em.02.03.07.

[4] K. Indajang, Jufrizen, and A. Juliandi, "The Influence of Organizational Culture and Principal Leadership on Teacher Competence and Performance at the Sultan Agung Pematangsiantar College Foundation," JUPIIS J. Educator. Social Sciences., vol. 12, no. 2, pp. 393-406, 2020.

[5] BE Damanik, "The Influence of Intellectual Ability and Work Motivation on Teacher Performance," Idaarah J. Manaj. Educator., vol. 2, no. 2, p. 143, 2018, doi:10.24252/idaarah.v2i2.6356.

[6] S. Liu and P. Hallinger, "Principal Instructional Leadership, Teacher Self-Efficacy, and Teacher Professional Learning in China: Testing a MediatedEffects Model," Educ. Adm. Q., vol. 54, no. 4, pp. 501528, 2018, doi:10.1177/0013161X18769048.

[7] Q. Zheng, L. Li, H. Chen, and S. Loeb, "What Aspects of Principal Leadership Are Most Highly Correlated With School Outcomes in China?," Educ. Adm. Q., vol. 53, no. 3, pp. 409-447, 2017, doi:10.1177/0013161X17706152.
[8] K. Leithwood, S. Patten, and D. Jantzi, "Testing A Conception Of How School Leadership Influences Student Learning," Educ. Adm. Q., vol. 46, no. 5, pp. 671-706, 2010, doi:10.1177/0013161X10377347.

[9] Suratman, Y. Arafat, and S. Eddy, "The Influence of Principal's Leadership and Teacher's Competence toward Teacher's Performance in Indonesia," J. Soc. Work Science. Educ., vol. 1, no. 2, pp. 96-104, 2020.

[10] D. Pianda, Teacher Performance: Teacher Competence, Work Motivation and Leadership. Sukabumi: CV. Traces, 2018.

[11] Torch, Principal Management and Leadership. Yogyakarta: ArRuzz Media, 2014.

[12] H. Fitria, M. Mukhtar, and M. Akbar, "The Effect of Organizational Structure and Leadership Style on Teacher Performance in Private Secondary School," IJHCM (International J. Hum. Cap. Manag., vol. 1, no. 02, pp. 101-112, 2017, doi: 10.21009/ijhcm.012.12.

[13] S. Purwoko, "The Influence of Principal Leadership, Teacher Commitment and Teacher Work Discipline and School Culture on Vocational Teacher Performance," $J$. Management Accountability. Educator., vol. 6, no. 2, pp. 149-162, 2018.

[14] Hardono, Haryono, and A. Yusuf, "Leadership of Principals, Academic Supervision, and Work Motivation in Improving Teacher Performance," Educ. Manag., vol. 6, no. 1, pp. 26-33, 2017, [Online]. Available: http://journal.unnes.ac.id/sju/index.php/eduman.

[15] Mahendra, Y. Arafat, and AA Setiawan, "The Influence of Internal Communication, Work Motivation, and Principal Leadership on Teacher Performance," GHAITSA Islam. Educ. J., vol. 1, no. 3, pp. 271-292, 2020.

[16] L. . Berry and J. . Houston,Psychology at Work: An Introduction to Industrial and Organizational Psychology. New York: McGraw-Hill International, 1993.

[17] E. Paramita, P. Lumbanraja, and Y. Absah, "The Influence of Organizational Culture and Organizational Commitment on Employee Performance and Job Satisfaction as a Moderating Variable at PT BankMandiri (Persero), Tbk," Int. J. Res. Rev., vol. 7 , no. March, p. 3, 2020

[18] MJ Ng'ang'a and W. Nyongesa, "The Impact of Organizational Culture on Performance of Educational Institutions," int. J. Bus. soc. science., vol. 3, no. 8, pp. 211-217, 2012, [Online]. Available: http://www.ijbssnet.com/journals/Vol_3_No_8_Special_ Issue April 2012/24.pdf.

[19] H. Hendra, "The Influence of Organizational Culture, Training and Motivation on Employee Performance at Tjut Nyak Dhien University Medan," Maneggio J. Ilm. Master of Management., vol. 3, no. 1, pp. 1-12, 2020, doi:10.30596/maneggio.v3i1.4813.

[20] A. Dirwan, "Analysis of the Influence of Organizational Culture and Commitment to the Performance of Private Higher Education Lecturers," J. Din. Educator., vol. 7, no. 3, pp. 133-141, 2014.

[21] Yulizar, Y. Arafat, and Rohana, "The Influence of Organizational Culture and Principal Leadership on 
Teacher Performance at SMA Negeri Tanjung Raja District," J. Intellect. Islam, Sos. and Science, vol. 9, no. 1, pp. 1-14, 2020.

[22] AO Olanipekun, IO Aje, and JO Falemu, Abiola, "Effects of Organizational Culture on the Performance of Quantity Surveying Firms in Nigeria," int. J. Humanity. soc. science., vol. 3, no. 5, pp. 206-215, 2013, doi:10.1111/j.1651-2227.1993.tb12933.x.

[23] Haryani and RU Cahyaningtyas, "The Influence of Intellectual Intelligence, Organizational Culture and Work Facilities on Teacher Performance at Sma Negeri 5 Purwokerto," Maj. Scientific Management and Business, vol. 14, no. 2, pp. 17-35, 2017.

[24] E. Widiyanti, Murwati, and TJ Raharjo, "The Influence of Principal Leadership, School Culture through Motivation on Junior High School Teacher Performance," Educ. Manag., vol. 7, no. 5, pp. 11-16, 2018.

[25] IM Sayer, M. Kristiawan, and M. Agustina, "Fairy Tale as a Medium for Children's Character Cooperation Building," Al-Talim J., vol. 25, no. 2, pp. 108-116, 2018, doi:10.15548/jt.v25i2.458.

[26] B. Lian, M. Kristiawan, D. Ammelia, G. Primasari, M. Anggi, and M. Prasetyo, "Teachers' Model in Building Students' Character," J. Crit. Rev., vol. 7, no. 14, pp. 927-932, 2020, doi:10.31838/jcr.07.14.165.

[27] Constitution, Law Number 14 of 2005 concerning Teachers and Lecturers. 2005.

[28] M. Hafid, "The Influence of Teacher Motivation and Competence on the Performance of School and Madrasah Teachers in the Salafiyah Syafi'iyah Islamic Boarding School Sukorejo," J. Educator. Indonesian Islam., vol. 1, no. 2, pp. 293-314, 2017, doi:10.35316/jpii.v1i2.55.

[29] Epa, "Teacher Performance Is Influenced By Teacher Competence And Principal Leadership," ALIGNMENTJournal Adm. Educ. Manag., vol. 3, no. 2, pp. 137-144, 2020.

[30] D. Hadian and I. Yuliyanti, "The Influence of Advisory Teacher Competencies, Organizational Climate, and Principal Leadership on the Performance of Supervisors in High Schools in Cimahi City," J. Eco. Entrep Business., vol. 5, no. 2, pp. 63-73, 2011, [Online]. Available: http://jurnal.stiepas.ac.id/index.php/jebe/article/view/9.

[31] MI Hamzah and E. Sarwoko, "Leadership, Organizational Culture and Performance: The Mediation Role of Work Motivation," J. Eco. mods., vol. 16, no. 1, pp. 41-53, 2020.

[32] S. Rahardjo, "The Effect of Competence, Leadership and Work Environment Towards Motivation and its Impact on the Performance of Teacher of Elementary School in Surakarta City, Central JAVA, Indonesia," int. J. Adv. res. Manag. soc. science., vol. 3, no. 6, pp. 5974, 2014, [Online]. Available: http://www.garph.co.uk/IJARMSS/June2014/7.pdf

[33] JF Hair, Multivariate Data Analysis, 7th Edition. New Jersey: Pearson Prentice Hall, 2014.

[34] PMPN Number, Minister of National Education Regulation number 13 of 2007 concerning Standards for
Principals / Madras. 2007.

[35] H. Fitria, "The Influence Of Organizational Culture And Trust Through The Teacher Performance In The Private Secondary School In Palembang," int. J. Sci. Technol. res., vol. 7, no. 7, pp. 82-86, 2018.

[36] A. Juliandi, "Structural Equation Model Based Partial Least Square (SEM-PLS): Using SmartPLS," 2018. https://zenodo.org/record/2538001\#.X-YIiFUzbIU (accessed Jun. 02, 2020)

[37] WW Chin, RA Peterson, and SP Brown, "Structural Equation Modeling In Marketing : Some Practical Reminders Structural Equation Modeling In Marketing : Some Practical Reminders," J. Mark. Theory Practice. ISSN, vol. 16, no. 4, pp. 287-298, 2008, doi:10.2753/MTP1069-6679160402.

[38] J. Sarwono, Making Thesis, Thesis and Dissertation with Partial Least Square SEM (PLS - SEM). Yogyakarta: Andi Offset, 2016.

[39] A. Mataputun, "Implementation of the Tasks of the School Committee in Improving the Quality of Education Services in Sma Negeri 2 Sarm Regency," NOKEN J. Educator Management., vol. 1, no. 1, pp. 10 21, 2020.

[40] A. Yaman, "The Influence of Principal Leadership, Teacher Professional Allowances, and School Climate on the Performance of State Vocational High School Teachers in Makassar City," Al-Musannif J. Islam. Educ. Teach. Trains., vol. 2, no. 1, pp. 29-48, 2020.

[41] M. Gandung, "The Influence of Principal Leadership and Organizational Culture on Teacher Performance (Case Study at the Ciputat Darussalam Education Foundation, South Tangerang City)," creative. J. Ilm. Management Study Program. Univ. Pamulang, vol. 7 , no. 1, pp. 103-114, 2019.

[42] WB Sulfemi, "The Effect of Confidence and Principal Leadership Style on Teacher Performance in Ciampea District, Bogor Regency," Nidomul Haq J. Educator Management. Islam, vol. 5, no. 2, pp. 157-179, 2019 doi:10.31227/osf.io/7qby3

[43] E. Juniarti, N. Ahyani, and A. Ardiansyah, "The Influence of Principal Leadership and Teacher Discipline on Teacher Performance," J. Educ. res., vol. 1, no. 3, pp. 193-199, 2020 doi:10,47467/reslaj.v1i2.108.

[44] F. Zakharia, "The Influence of Organizational Culture and Job Satisfaction on Teacher Performance at SMP Yadika 3 Tangerang," J. Economics. and Sausage., vol. 3, no. 1, pp. 39-50, 2014.

[45] Komarudin, "The Influence of Organizational Culture on Teacher Performance at State Elementary School 06 Ciputat," J. Lively, vol. 1, no. 2, pp. 78-86, 2018, doi:10.31933/jimt.v1i1.33.

[46] AFN Ahmad, S. Haerani, N. Hamid, and A. Reni, "The Influence of Organizational Culture, Organizational Commitment and Job Satisfaction on the Performance of High School Teachers in Makassar," Hasanuddin J. Appl. Buses. Entrep., vol. 2, no. 2, pp. 90-99, 2019.

[47] A. Rivai, "The Influence of Transformational Leadership and Organizational Culture on Employee Performance," MANEGGGIO J. Ilm. Master of Management., vol. 3 , 
no. 2, pp. 213-223, 2020, doi:10.22219/jtiumm.vol19.no2.118-126.

[48] C. Nurviza, Yusrizal, and N. Usman, "The Influence of Organizational Culture and Principal Leadership on Teacher Performance at Sma Unggul Negeri 2 Boarding School in Banda Aceh City," J. Masters Adm. Educator., vol. 7, no. 1, pp. 41-46, 2019.

[49] GE Pakpahan, S. Nababan, J. Simanjuntak, and A. Sudirman, "The influence of organizational culture, communication and teacher competence on teacher performance in Sultan Agung Pematangsiantar private high school," J. Performance, vol. 16, no. 2, pp. 131138, 2019, [Online]. Available: http://journal.feb.unmul.ac.id/index.php/KINERJA

[50] H. Muhammad Arifin, "The influence of competence, motivation, and organizational culture to high school teacher job satisfaction and performance," int. Educ. Studs., vol. 8, no. 1, pp. 38-45, 2015, doi:10.5539/ies.v8n1p38.

[51] I. Mulyasari, "The Effect of Emotional Intelligence and Competence on Employee Performance," J. Manag. Rev., vol. 2, no. 2, p. 190, 2019, doi:10.25157/jmr.v2i2.1786.

[52] D. Narsih, "The Influence of Competence and Job Satisfaction on Teacher Performance at SMKN 23 North Jakarta," Util. J. Ilm. Educator. and Eco., vol. 1, no. 1, pp. 94-102, 2017.

[53] Y. Sukamto and P. Pardjono, "The Influence of Teacher Competence, Work Commitment and Work Motivation on the Performance of Mainstay Middle School Teachers in Sleman," J. Researcher. Educator Science., vol. 9, no. 2, p. 165, 2016, doi:10.21831/jpipfip.v9i2.12917.

[54] S. Manik and N. Syafrina, "The Influence of Competence on the Performance of Lecturers at the Riau Economics College," J. Ilm. icon. and Business, vol. 11, no. 1, pp. 1-6, 2018.

[55] A. Sopandi, "The Influence of Professional Competence and Personality Competence on Teacher Performance," science. J. Reflect., vol. 2, no. 2, pp. 121-130, 2019, doi:10.5281/zenodo.2628070.

[56] B. Sulistyo, MM Minarsih, and MM Warso, "The Influence of Teacher Professional Education and Training (PLPG), Teacher Discipline, and Teacher Competence on Teacher Performance in Jepara Middle School," J. Manage., vol. 2, no. 2, 2016.

[57] Ritunjoy Bhuyan. (2021). Design Procedure of A Permanent Magnet DC Commutator Motor. International Journal of Science and Society, 3(1), 1118. https://doi.org/10.200609/ijsoc.v3i1.262

[58] Sugiono, E., Efendi, S., \& Afrina, Y. (2021). The Effect of Training, Competence and Compensation on the Performance of New Civil Servants with Organizational Culture as Intervening: Studies at the Ministry of Health of the Republic of Indonesia. International Journal of Science and Society, 3(1), 262-279. https://doi.org/10.200609/ijsoc.v3i1.292 